\title{
RISK ASSESSMENT OF CONSTRUCTION PROJECTS
}

\author{
Edmundas Kazimieras Zavadskas ${ }^{1}$, Zenonas Turskis ${ }^{2}$, Jolanta Tamošaitiené $\dot{e}^{3}$ \\ Vilnius Gediminas Technical University, \\ Department of Construction Technology and Management, Saulettekio al. 11, LT-10223 Vilnius, Lithuania \\ E-mails: ${ }^{1}$ edmundas.zavadskas@vgtu.lt; ${ }^{2}$ zenonas.turskis@vgtu.lt; ${ }^{3}$ jolanta.tamosaitiene@vgtu.lt \\ Received 18 Feb. 2009; accepted 23 Nov. 2009
}

\begin{abstract}
The paper presents risk assessment of construction projects. The assessment is based on the multi-attribute decision-making methods. The risk evaluation attributes are selected taking into consideration the interests and goals of the stakeholders as well as factors that have influence on the construction process efficiency and real estate value. Ranking of objects and determination of their optimality are determined by applying TOPSIS grey and COPRAS-G methods with attributes values determined at intervals. A background and a description of the proposed model are provided and key findings of the analysis are presented.
\end{abstract}

Keywords: decision- making, construction, project, risk, assessment, multi-attribute, TOPSIS grey, COPRAS-G.

\section{Introduction}

The risk factor in construction business is very high. Construction objects are unique and built only once. Construction objects life cycle is full of various risks. Risks come from many sources: temporary project team that is collected from different companies, construction site, etc. Moreover, the size and complexity of construction objects are increasing which adds to the risks. This is in addition to the political, economic, social conditions where the object is to be undertaken. Object risk can be defined as an uncertain event or condition that, if it occurs, has a positive or negative effect on at least one project objective, such as time, cost, quality (Project Management Institute Standards Committee 2004). The risks cause cost and time overruns in construction projects.

\section{Description of the risk assessment model}

Risk management is activity process about defining sources of uncertainty (risk identification), estimating the consequences of uncertain events/conditions (risk analysis), generating response strategies in the light of expected outcomes and finally, based on the feedback received on actual outcomes and risks emerged, carrying out identification, analysis and response generation steps repetitively throughout the life cycle of an object to ensure that the project objectives are met. Risk management in construction is a tedious task as the objective functions tend to change during the object life cycle (Dikmen et al. 2008). Tserng et al. (2009) presented a study of ontologybased risk management framework of construction projects through project life cycle variance - covariance. Risk value model for currency market is presented by Aniūnas et al. (2009). Isaac and Navon (2009) described models of building projects as a basis for change control.
Risk management processes of construction project describe the work of all project life cycle. The risk assessment problem is analysed by many authors (Shevchenko et al. 2008; Suhobokov 2008; Zavadskas et al. 2008a; Zavadskas and Vaidogas 2008; Schieg 2008, 2009; Šarka et al. 2008). Proper risk allocation in construction contracts has come to assume prominence because risk identification and risk allocation have a clear bearing on risk handling decisions (Perera et al. 2009).

Hassanein and Afify (2007) analysed risk indentification procedure for construction contracts. Albert et al. (2008) pointed on the investigated risk assessment. ElSayegh (2008) presented risk assessment and allocation problem, Han et al. (2008) described web-based integrated system, Gao (2009) presented strategies with the risk adjustment. Graves and Ringuest (2009) analysed probabilistic dominance criteria for comparing uncertain alternatives. Lahdelma et al. (2009) investigated uncertainties in multi-criteria decision problems.

Cost-effective solutions that meet the performance criteria can be achieved, especially if the principle of whole-life costing is being adopted (Straub 2009). The risk management in construction object's life cycle stages can be divided into: macro, meso and micro levels (Fig. 1). The project life cycle includes five steps of process management:

- Initiating;

-Planning;

-Executing;

- Monitoring and Controlling;

-Closing.

The process of risk management can be divided into three stages:

-Identification;

- Analysis;

- Control. 


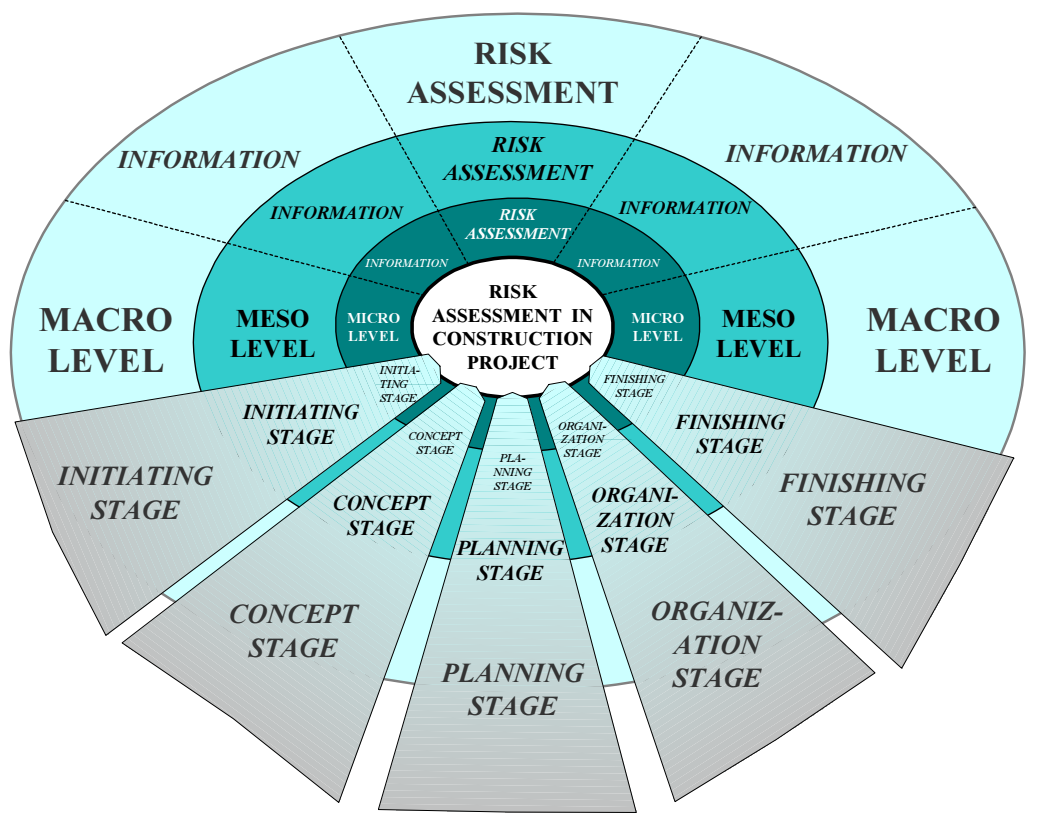

Fig. 1. Risk assessment divided according to object life cycle environment

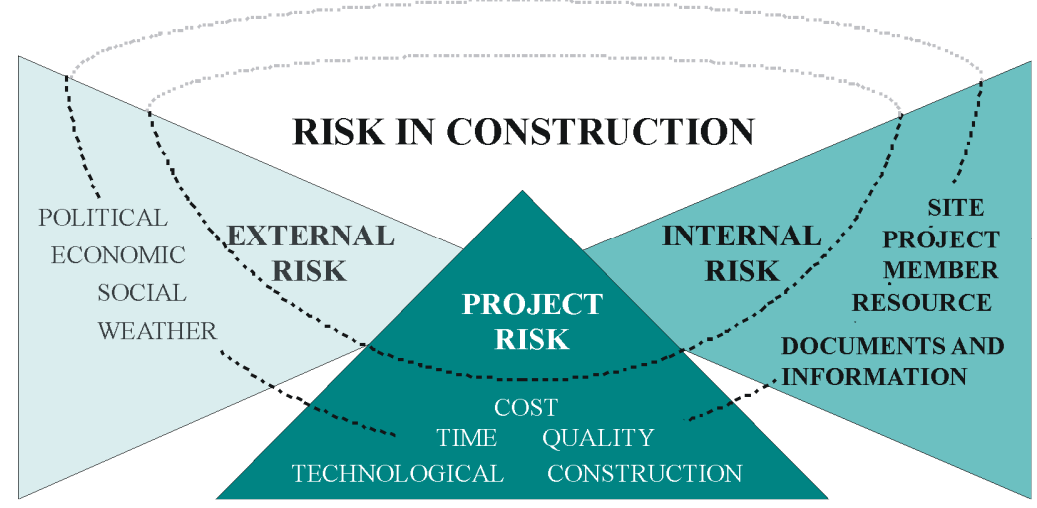

Fig. 2. Risk allocation structure by level in construction object

The risk management process in construction is extreme and important. Risk measure includes risk level determination of each objective and the risk analysis estimation by applying various approaches and technology. Risk control process evaluates performance of risk control.

\subsection{Risk identification}

Risk identification is the first and main step of risk management process. It is describing the competitiveness conditions and the clarification of risk and uncertainty factors (Rutkauskas 2008; Zayed et al. 2008), recognition of potential sources of risk and uncertainty event responsibilities. The project risks can be divided into three groups:

\section{- External; \\ -Project; \\ - Internal.}

External risks are those risks that are beyond the control of the project management team. Internal risks can be divided according to the party who might be the originator of risk events such as stakeholders, designer, contractor, etc. There are various classification ways of risk management methods.

The risk allocation structure of construction objects is presented in Fig. 2.

\section{External risks (environmental criteria): \\ - Political risk; \\ - Economic risk; \\ -Social risk; \\ - Weather risk.}

Political risks. There are changes in government laws of legislative system, regulations and policy and improper administration system, etc. (Li and Liao 2007).

Economic risks. There is inconstancy of economy in the country, repayment situation in manufacture sphere, inflation and funding. Considering the current economic situation, this result can be reasonably expected. Tvaronavičienè and Grybaite (2007) analysed Lithuanian economic activities in construction. Economic disasters, as referred to herein, are periodic economic disasters of such magnitude that a contractor could not properly assess either their probability or their cost impact. 
Social risks are the growing importance to any effort at risk allocation. It is an area in which political and social pressures from parties having little interest in a project but having a great impact on such a project greatly influence its outcome. The impact of the financial aid on social and economic development of the region is analysed by Ginevičius and Podvezko (2009), risk communication in organizations is analysed by Conchie and Burns (2008).

Weather risk. Except for extremely abnormal conditions, it is a risk for the contractor to assume, as its impact on construction methods can by assessed by the contractor.

Project risks (construction process criteria):

- Time risk;

- Cost risk;

- Work quality;

- Construction risk;

- Technological risk.

Time risk can be determined by appraisal of the delay at construction, technology and for all works.

Cost risk. The cost of opportunity product rises due to neglecting of management (Zavadskas et al. 2008a).

Work quality. Deflective work is considered a significant risk factor in this category because not only does it result in construction delays and additional cost to the contractor but it easily leads to disputes on the liability for the deflection.

Construction risk. The risks are involved in construction delay, changes in the work and construction technology.

Technological risk. Designing errors; lack of technologies; management errors; shortage of the qualified labour.

Internal risks (intrinsic criteria):

- Resource risk;

- Project member risk;

- Construction site risk;

- Documents and information risk.

Resource risk. Materials and equipment involve considerable risks. The availability and productivity of the resources necessary to construct the project are risks which are proper for the contractor to assume (Fisk 2003).

Project member risk. Team risk refers to issues associated with the project team members, which can increase the uncertainty of a project's outcome, such as team member turnover, staffing build up, insufficient knowledge among team members, cooperation, motivation, and team communication issues.

Stakeholders' risks rightfully belong to the stakeholder alone and should be retained by stakeholders except to the extent that they are influenced by construction methods determined by the contractor, or created by suppliers controlled by the contractor. Stakeholders' influence on the external environment is analysed by Mitkus and Šostak (2008).

Designers risk. The expansion of construction has placed great burdens upon the design professions. Main- taining performance standards in the face of this is quite difficult, and occasionally, design or specification deflections occur that create construction problems. Design failures or constructability errors are becoming more and apparent, and the architect should bear the true cost of such failures.

Contractor risk. The prime or general contractors are in the best position to assess the capacity of their subcontractors, and therefore it is they who should bear the risk of not assessing the risk properly.

Subcontractor risk is that is properly assumed by the contractor except where it arises from one of the other listed risks attributable to stakeholder or architect (Fisk, 2003).

Suppliers risk. Default from obligations of the supplier (Fisk 2003).

Team risk. Team risk refers to issues associated with the project team members that can increase the uncertainty of a project's outcome, such as team member turnover, staffing build up, insufficient knowledge among team members, cooperation, motivation, and team communication issues. Working team must analyse the business activities of all alliance members and identify various risk factors in business activities and their characters (Gunstone 2003; Li and Liao 2007; Li et al. 2007).

Construction site risk. Accident exposures in workplace are inherent in the nature of the work and are best assessed by the contractors and their insurance and safety advisors (Fisk 2003).

Documents and information risk assumes: contradiction in documents; pretermission; legal and communication. Changed order negotiation and delayed dispute resolution are significant risks during project construction. Communication is very important at all construction period and after finishing construction work.

Protracted negotiation on disputes or valuation of changed work is undesirable to most contractors.

Connections of the contractors with subcontractors and suppliers are analysed by Mitkus and Trinkūnienè (2008).

\subsection{Risk analysis and control}

Risk analysis. Risk and uncertainty rating identifies the importance of the sources of risk and uncertainty about the goals of the project. Risk assessment is accomplished by estimating the probability of occurrence and severity of risk impact.

More detailed information available in the construction process can be effectively used for traditional risk management schemes such as risk control. Risk control can be described as the five-stage process (Han et al. 2008):

$$
\begin{aligned}
& \text {-Identification; } \\
& \text {-Analysis; } \\
& \text {-Evaluation; } \\
& \text {-Response; } \\
& \text {-Monitoring. }
\end{aligned}
$$




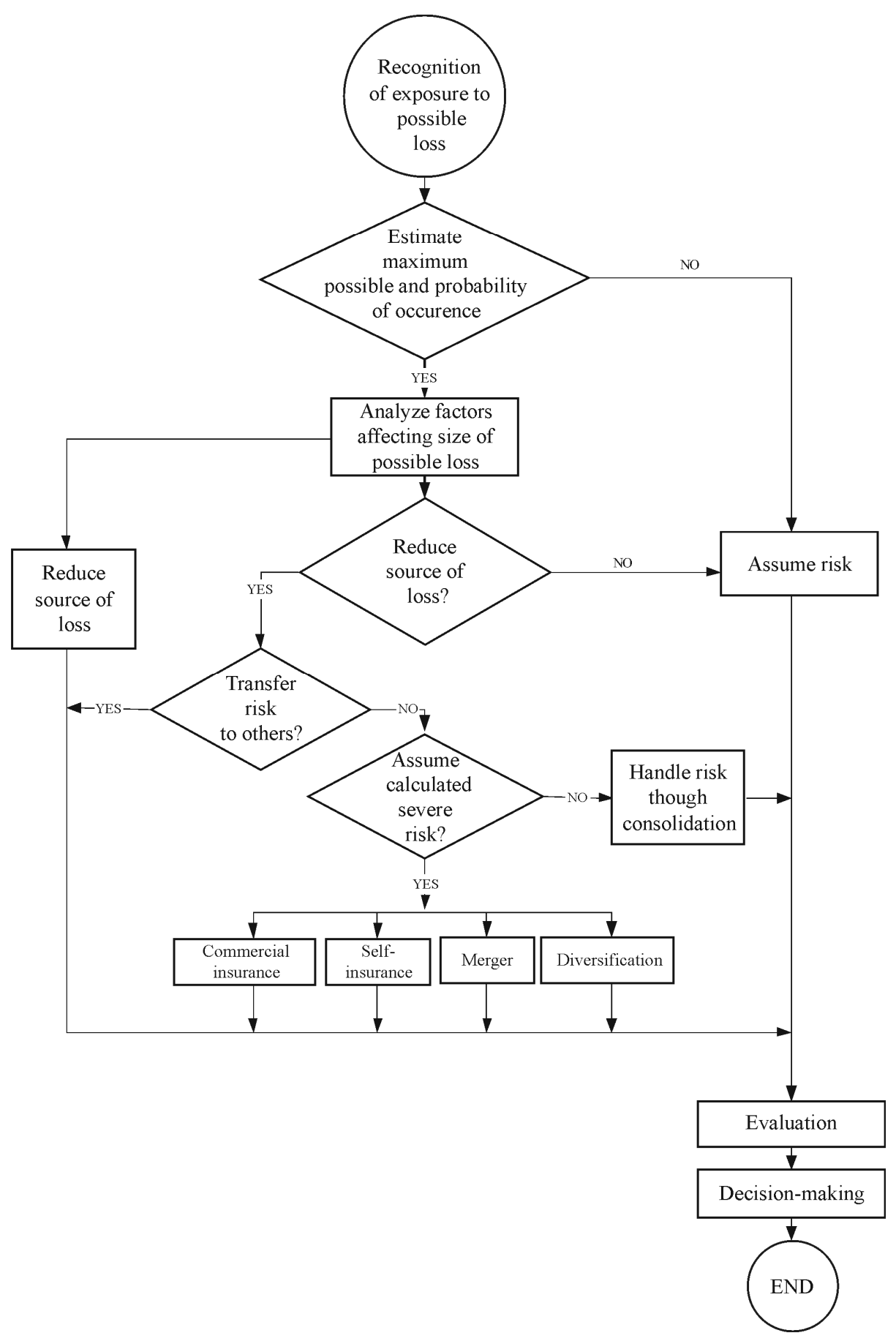

Fig. 3. Decision making model of risk assessment

Risk control establishes a plan, which reduces or eliminates sources of risk and uncertainty impact on the project's deployment.

Options available for mitigation are:

- Commercial insurance;

- Self-insurance;

- Merger and diversification.

Decision making model of risk assessment is shown in Fig. 3.

This model must be filled at every turn of risk management process.

\section{Grey research methodology of risk assessment}

\subsection{Grey system theory}

Deng (1982) developed the Grey system theory. Grey relational analysis possesses advantages (Deng 1988, 1989):

-involves simple calculations,

- requires smaller samples,

- a typical distribution of samples is not needed,

-the quantified outcomes from the Grey relational grade do not result in contradictory conclusions to qualitative analysis and 
- the Grey relational grade model is a transfer functional model that is effective in dealing with discrete data.

The risk assessment always deals with future and values of criteria cannot be expressed exactly. This multi-criteria decision-making problem can be determined not with exact criteria values, but with fuzzy values or with values at some intervals (Fig. 4).
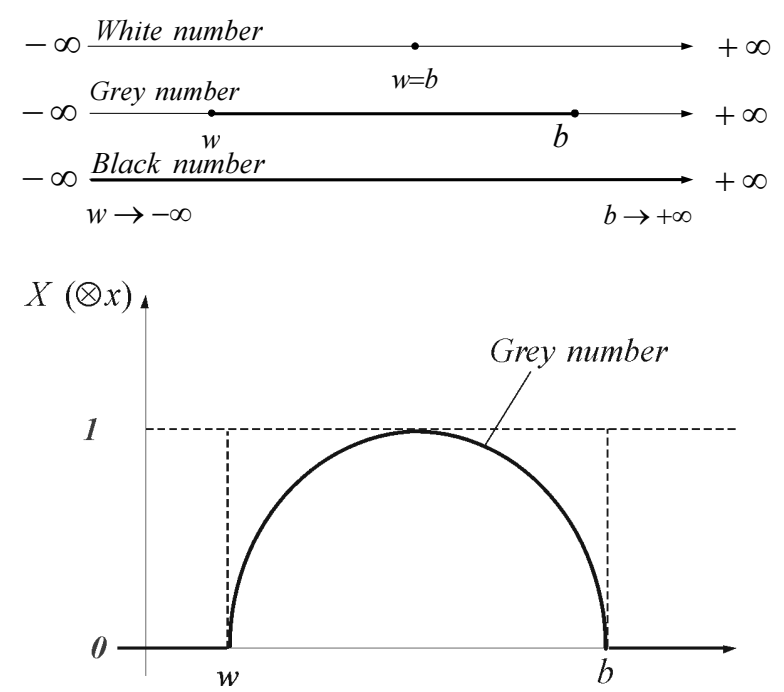

Fig. 4. White, grey and black numbers by Deng (Yamaguchi et al. 2007)

The Deng's grey numbers are given as follows:

$$
X(k, \otimes x)=\left\{\begin{array}{c}
{[0,1] k \in[w, b]} \\
0 k<w, b<k
\end{array}\right\} .
$$

The use of grey relational analysis in solving multiple attribute decision-making problems is analysed by Kuo et al. (2008) and Cakir (2008).

Grey theory was applied in evaluating of national economic strength (Lin and Liu 2007), selection of an ERP system and intelligent sensors (Yang et al. 2007) and in the assessment of information security (Shen et al. 2009).

\subsection{MADM methods for solving the problem}

Multiple attributes decision aid provides several powerful solution tools (Hwang and Yoon 1981; Figueira et al. 2005) for confronting sorting the problems. There can be used very simplified techniques for the evaluation such as the Simple Additive Weighting - SAW; TOPSIS Technique for Order Preference by Similarity to Ideal Solution (Hwang and Yoon 1981).

A more detailed survey of multi-attribute decisionmaking methods in the construction context is presented by many authors. Zavadskas and Antuchevičienè (2006) presented construction objects renewal modelling by applying multi-attribute evaluation of rural buildings' regeneration alternatives; the multi-alternative design and multiple criteria analysis of the life cycle of a building is described by Banaitienè et al. (2008); selection of the effective dwelling house walls by applying attribute values determined at intervals is described by Zavadskas et al. $(2008 \mathrm{c})$.

The purpose is to be achieved by using attributes of effectiveness, which have different dimensions, different significances as well as different directions of optimization (Kendall 1970; Zavadskas 1987). The discrete criteria values can be normalized by applying different normalization methods (Zavadskas and Turskis 2008; Ginevičius 2008). The purpose of analysis also can be different (Kaklauskas et al. 2007; Ginevicius et al. 2007; Bregar et al. 2008). Multiple criteria decision aid (Hwang and Yoon 1981) provides several powerful and effective tools (Figueira et al. 2005; Zavadskas et al. 2008b; Dzemyda et al. 2007; Ginevičius et al. 2008a, b; Ginevičius and Podvezko 2009) for confronting sorting the problems.

There is a wide range of methods (Ulubeyli and Kazaz 2009; Jakimavicius and Burinskiene 2009a, b; Plebankiewicz 2009; Liaudanskiene et al. 2009; Liu 2009; Dytczak and Ginda 2009; Podvezko 2009) based on multi-criteria utility theory: SAW - Simple Additive Weighting (Ginevičius et al. 2008b); SAW-G (Zavadskas et al. 2010); MOORA - Multi-Objective Optimization on the basis of Ratio Analysis (Brauers and Zavadskas 2006; Brauers et al. 2007, 2008a, b; Kalibatas and Turskis 2008); TOPSIS - Technique for Order Preference by Similarity to Ideal Solution (Hwang and Yoon 1981); VIKOR - compromise ranking method (Opricovic and Tseng 2004); COPRAS - COmplex PRoportional ASsessment (Zavadskas and Kaklauskas 1996); Game theory methods (Zavadskas and Turskis 2008; Peldschus 2008, 2009; Ginevičius and Krivka 2008; Turskis et al. 2009) and other methods (Turskis 2008).

TOPSIS is a method to identify solutions from a finite set of alternatives based upon simultaneous minimization of distance from an ideal point and maximization of distance from a negative ideal point. The TOPSIS method was developed by Hwang and Yoon (1981). The only subjective input needed is relative weights of attributes. An extension of TOPSIS for group decision making is analysed by Shih et al. (2007) and incremental analysis of MCDM with an application to group TOPSIS is developed by Shih (2008). Lin et al. (2008) applied TOPSIS method with grey number operations.

The COPRAS method determines a solution with the ratio to the ideal solution and the ratio with the idealworst solution. Zavadskas et al. (2008c, d) applied COPRAS-G method with grey number operations to the problem with uncertain information.

The algorithm of problem solution applying TOPSIS grey and COPRAS-G methods is presented in Fig. 5. Either method is applicable to the solution of problems in construction: Lin et al. (2008) applied TOPSIS method with grey number operations to the contractor selection problem solution with uncertain information. Zavadskas et al. (2008c) applied COPRAS-G method with grey number operations to the selection of the effective dwelling house walls problem with uncertain information, Zavadskas et al. (2009). 


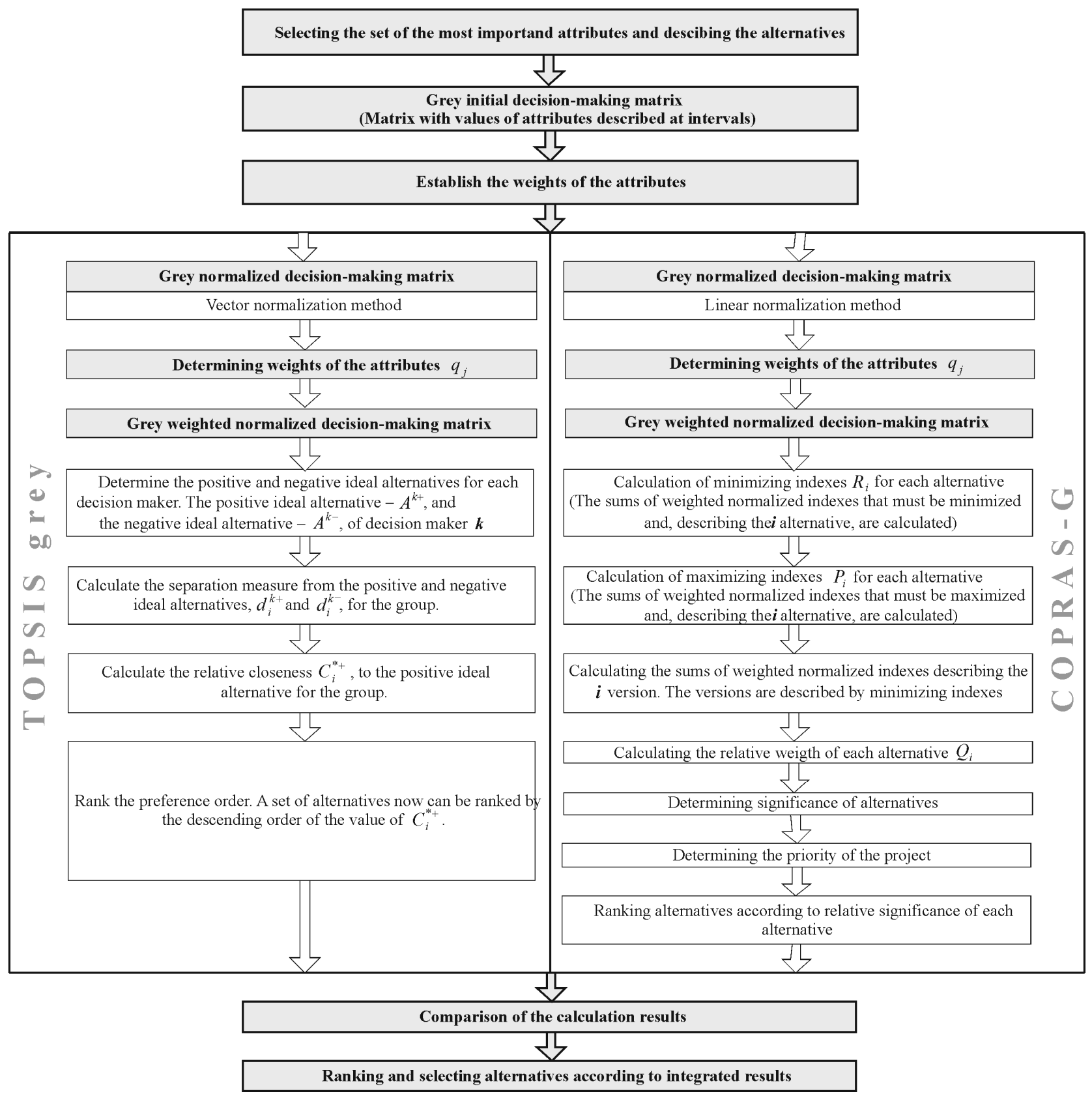

Fig. 5. The main algorithm of problem solution applying TOPSIS grey and COPRAS-G methods

\subsubsection{TOPSIS method with attributes values determined at intervals}

The TOPSIS method is one of the best described mathematically and not simple for practical using. Lin et al. (2008) proposed the model of TOPSIS method with attributes values determined at intervals which includes the following steps:

Step 1: Selecting the set of the most important attributes, describing the alternatives;

Step 2: Constructing the decision-making matrix $\otimes X$. Grey number matrix $\otimes X$ can be defined as:

$$
\otimes X^{k}=\left[\begin{array}{cccc}
\otimes x_{11}^{k} & \otimes x_{12}^{k} & \ldots & \otimes x_{1 m}^{k} \\
\otimes x_{21}^{k} & \otimes x_{22}^{k} & \ldots & \otimes x_{2 m}^{k} \\
\vdots & \vdots & \ddots & \vdots \\
\otimes x_{n 1}^{k} & \otimes x_{n 2}^{k} & \ldots & \otimes x_{n m}^{k}
\end{array}\right] ; i=\overline{1, n} ; \quad j=\overline{1, m}
$$

where $\otimes x_{i j}^{k}$ denotes the grey evaluations of the $i$-th alternative with respect to the $j$-th attribute by decision maker $k(k=1, \ldots, K) ;\left[\otimes x_{i 1}^{k}, \otimes x_{i 2}^{k}, \ldots, \otimes x_{i m}^{k}\right]$ is the grey number evaluation series of the $i$-th alternative given by decision maker $k$. It is noted that there should be $K$ grey decision matrices for the $K$ members of the group. 
Step 3: Establish the weights of the attributes $q_{j}$.

Step 4: Construct the normalized grey decision matrices:

$$
\otimes \bar{x}_{i j, b}^{k}=\frac{\otimes x_{i j}^{k}}{\max _{i}\left(b_{i j}^{k}\right)}=\left(\frac{w_{i j}^{k}}{\max _{i}\left(b_{i j}^{k}\right)}, \frac{b_{i j}^{k}}{\max _{i}\left(b_{i j}^{k}\right)}\right) .
$$

On the other hand, the normalization of the smallerthe-better type attribute can be calculated as:

$$
\otimes \bar{x}_{i j, w}^{k}=-\frac{\otimes x_{i j}^{k}}{\min _{i}\left(w_{i j}^{k}\right)}+2=\left(\frac{-b_{i j}^{k}}{\min _{i}\left(w_{i j}^{k}\right)}+2 ; \frac{-w_{i j}^{k}}{\min _{i}\left(w_{i j}^{k}\right)}+2\right)
$$

Step 5: Determining weights of the attributes $q_{j}$.

Step 6: Construct the grey weighted normalized decision making matrix.

Step 7: Determine the positive and negative ideal alternatives for each decision maker. The positive ideal alternative $-A^{k+}$, and the negative ideal alternative $-A^{k-}$, of decision maker $k$ can be defined as:

$$
\begin{gathered}
A^{k+}=\left\{\left(\max _{i} b_{i j}^{k} \mid j \in J\right),\left(\min _{i} w_{i j}^{k} \mid j \in J^{\prime}\right) \mid i \in n\right\}= \\
{\left[x_{1}^{k+}, x_{2}^{k+}, \ldots, x_{m}^{k+}\right] \text { and }} \\
A^{k-}=\left\{\left(\min _{i} w_{i j}^{k} \mid j \in J\right),\left(\max _{i}^{k} b_{i j}^{k} \mid j \in J^{\prime}\right) \mid i \in n\right\}= \\
{\left[x_{1}^{k-}, x_{2}^{k-}, \ldots, x_{m}^{k-}\right] .}
\end{gathered}
$$

Step 8: Calculate the separation measure of the positive and negative ideal alternatives, $d_{i}^{k+}$ and $d_{i}^{k-}$, for the group. There are two sub-steps to be considered: the first one concerns the separation measure for individuals; the second one aggregates their measures for the group.

Step 8.1: Calculate the measures of the positive and negative ideal alternatives individually. For decision maker $\mathrm{k}$, the separation measures of the positive ideal alternative $-d_{i}^{k+}$ and negative ideal alternative $-d_{i}^{k-}$ are computed through weighted grey number as:

$$
\begin{aligned}
& d_{i}^{k+}=\left\{\frac{1}{2} \sum_{j=1}^{m} q_{j}\left[\left|x_{j}^{k+}-\bar{w}_{i j}^{k}\right|^{p}+\left|x_{j}^{k+}-\bar{b}_{i j}^{k}\right|^{p}\right]\right\}^{1 / p} ; \\
& d_{i}^{k-}=\left\{\frac{1}{2} \sum_{j=1}^{m} q_{j}\left[\left|x_{j}^{k-}-\bar{w}_{i j}^{k}\right|^{p}+\left|x_{j}^{k-}-\bar{b}_{i j}^{k}\right|^{p}\right]\right\}^{1 / p} .
\end{aligned}
$$

In equations (6) and (7), for $p \geq 1$ and integer, $q_{j}$ is the weight for the attribute $j$ which can be determined by attributes' weight determination methods. If $p=2$, then the metric is a weighted grey number Euclidean distance function. Equations (6) and (7) will be as follows:

$$
d_{i}^{k+}=\sqrt{\frac{1}{2} \sum_{j=1}^{m} q_{j}\left[\left|x_{j}^{k+}-\bar{w}_{i j}^{k}\right|^{2}+\left|x_{j}^{k+}-\bar{b}_{i j}^{k}\right|^{2}\right]},
$$

$$
d_{i}^{k-}=\sqrt{\frac{1}{2} \sum_{j=1}^{m} q_{j}\left[\left|x_{j}^{k-}-\bar{w}_{i j}^{k}\right|^{2}+\left|x_{j}^{k-}-\bar{b}_{i j}^{k}\right|^{2}\right]} .
$$

Step 8.2: Aggregate the measures for the group. The group separation measure of each alternative will be aggregated through an operation, $\otimes$ for all decision makers. Thus, the two group measures of the positive and negative ideal alternatives: $d_{i}^{*+}$ and $d_{i}^{*-}$, respectively, are the following two equations:

$$
\begin{aligned}
& d_{i}^{*^{+}}=\otimes d_{i}^{1+}, \ldots, \otimes d_{i}^{K+} \text { for alternative } i, \text { and (11) } \\
& d_{i}^{{ }^{*-}}=\otimes d_{i}^{1-}, \ldots, \otimes d_{i}^{K-} \text { for alternative } i .
\end{aligned}
$$

Geometric mean is adopted, and the group measures of each alternative will be:

$$
\begin{aligned}
& d_{i}^{*+}=\left(\prod_{k=1}^{K} d_{i}^{k+}\right)^{1 / K}, \text { for alternative } i, \\
& d_{i}^{*-}=\left(\prod_{k=1}^{K} d_{i}^{k-}\right)^{1 / K}, \text { for alternative } i .
\end{aligned}
$$

Step 9: Calculate the relative closeness $C_{i}^{*_{+}}$, to the positive ideal alternative for the group. The aggregation of relative closeness for the $i$-th alternative with respect to the positive ideal alternative of the group can be expressed as:

$$
C_{i}^{*_{+}}=\frac{d_{i}^{*-}}{d_{i}^{*+}+d_{i}^{*-}}
$$

where $0 \leq C_{i}^{*+} \leq 1$. The larger the index value is, the better evaluation of alternative will be.

Step 10: Rank the preference order. A set of alternatives now can be ranked by the descending order of the value of $C_{i}^{*+}$.

\subsubsection{COPRAS-G method with attributes values determined at intervals}

The procedure of using the COPRAS-G method includes the following steps:

Step 1: Selecting the set of the most important attributes, describing the alternatives;

Step 2: Constructing the grey decision-making matrix $\otimes X$ :

$$
\begin{gathered}
\otimes X=\left[\begin{array}{cccc}
{\left[\otimes x_{11}\right]} & {\left[\otimes x_{12}\right]} & \ldots & {\left[\otimes x_{1 m}\right]} \\
{\left[\otimes x_{21}\right]} & {\left[\otimes x_{22}\right]} & \ldots & {\left[\otimes x_{2 m}\right]} \\
\vdots & \vdots & \ddots & \vdots \\
{\left[\otimes x_{n 1}\right]} & {\left[\otimes x_{n 2}\right]} & \ldots & {\left[\otimes x_{n m}\right]}
\end{array}\right]= \\
{\left[\begin{array}{cccc}
{\left[w_{11} ; b_{11}\right]} & {\left[w_{12} ; b_{12}\right]} & \ldots & {\left[w_{1 m} ; b_{1 m}\right]} \\
{\left[w_{21} ; b_{21}\right]} & {\left[w_{22} ; b_{22}\right]} & \ldots & {\left[w_{2 m} ; b_{2 m}\right]} \\
\vdots & \vdots & \ddots & \vdots \\
{\left[w_{n 1} ; b_{n 1}\right]} & {\left[w_{n 2} ; b_{n 2}\right]} & \ldots & {\left[w_{n m} ; b_{n m}\right.}
\end{array}\right]} \\
i=\overline{1, n} ; j=\overline{1, m},
\end{gathered}
$$


where $\otimes x_{i j}$ is determined by $w_{i j}$ and $b_{i j}$.

Step 3: Establishing the weights of the attributes $q_{j}$.

Step 4: Normalizing the decision-making matrix $\otimes X$ :

$$
\begin{gathered}
\bar{w}_{i j}=\frac{w_{i j}}{\frac{1}{2}\left(\sum_{i=1}^{n} w_{i j}+\sum_{i=1}^{n} b_{i j}\right)}=\frac{2 w_{i j}}{\sum_{i=1}^{n} w_{i j}+\sum_{i=1}^{n} b_{i j}} ; \\
\bar{b}_{i j}=\frac{b_{i j}}{\frac{1}{2}\left(\sum_{i=1}^{n} w_{i j}+\sum_{i=1}^{n} b_{i j}\right)}=\frac{2 b_{i j}}{\sum_{i=1}^{n}\left(w_{i j}+b_{i j}\right)} ; \\
i=\overline{1, n} \text { and } j=\overline{1, m} .
\end{gathered}
$$

In formula (17), $w_{i j}$ is the lower value of the $j$ attribute in the alternative $i$ of the solution; $b_{i j}$ is the upper value of the attribute $j$ in the alternative $i$ of the solution; $m$ is the number of attributes; $n$ is the number of the alternatives compared.

Then, the decision-making matrix is normalized:

$$
\begin{gathered}
\otimes \bar{X}=\left[\begin{array}{cccc}
{\left[\otimes \bar{x}_{11}\right]} & {\left[\otimes \bar{x}_{12}\right]} & & {\left[\otimes \bar{x}_{1 m}\right]} \\
{\left[\otimes \bar{x}_{21}\right]} & {\left[\otimes \bar{x}_{22}\right]} & \ldots & {\left[\otimes \bar{x}_{2 m}\right]} \\
\vdots & \vdots & \ddots & \vdots \\
{\left[\otimes \bar{x}_{n 1}\right]} & {\left[\otimes \bar{x}_{n 2}\right]} & \ldots & {\left[\otimes \bar{x}_{n m}\right]}
\end{array}\right]= \\
{\left[\begin{array}{cccc}
{\left[\bar{w}_{11} ; \bar{b}_{11}\right]} & {\left[\bar{w}_{12} ; \bar{b}_{12}\right]} & \ldots & {\left[\bar{w}_{1 m} ; \bar{b}_{1 m}\right]} \\
{\left[\bar{w}_{21} ; \bar{b}_{21}\right]} & {\left[\bar{w}_{21} ; \bar{b}_{22}\right]} & \ldots & {\left[\bar{w}_{2 m} ; \bar{b}_{2 m}\right]} \\
\vdots & \vdots & \ddots & \vdots \\
{\left[\bar{w}_{n 1} ; \bar{b}_{n 1}\right]} & {\left[\bar{w}_{n 2} ; \bar{b}_{n 2}\right]} & \ldots & {\left[\bar{w}_{n m} ; \bar{b}_{n m}\right]}
\end{array}\right] .}
\end{gathered}
$$

Step 5: Determining weights of the attributes $q_{j}$.

Step 6: Calculating the weighted normalized decision matrix $\otimes \hat{X}$. The weighted normalized values $\otimes \hat{x}_{i j}$ are calculated as follows:

$$
\otimes \hat{x}_{i j}=\otimes \bar{x}_{i j} \cdot q_{j} ; \hat{w}_{i j}=\bar{w}_{i j} \cdot q_{j} \hat{b}_{i j}=\bar{b}_{i j} \cdot q_{j} .
$$

In formula (19), $q_{j}$ is the weight of the $j$-th attribute.

$$
\begin{gathered}
\otimes \hat{X}=\left[\begin{array}{cccc}
{\left[\otimes \hat{x}_{11}\right]} & {\left[\otimes \hat{x}_{12}\right]} & \ldots & {\left[\otimes \hat{x}_{1 m}\right]} \\
{\left[\otimes \hat{x}_{21}\right]} & {\left[\otimes \hat{x}_{21}\right]} & \ldots & {\left[\otimes \hat{x}_{2 m}\right]} \\
\vdots & \vdots & \ddots & \vdots \\
{\left[\otimes \hat{x}_{n 1}\right]} & {\left[\otimes \hat{x}_{n 2}\right]} & \ldots & {\left[\otimes \hat{x}_{n m}\right]}
\end{array}\right]= \\
{\left[\begin{array}{cccc}
{\left[\hat{w}_{11} ; \hat{b}_{11}\right]} & {\left[\hat{w}_{12} ; \hat{b}_{12}\right]} & \ldots & {\left[\hat{w}_{1 m} ; \hat{b}_{1 m}\right]} \\
{\left[\hat{w}_{21} ; \hat{b}_{21}\right]} & {\left[\hat{w}_{21} ; \hat{b}_{22}\right]} & \ldots & {\left[\hat{w}_{2 m} ; \hat{b}_{2 m}\right]} \\
\vdots & \vdots & \ddots & \vdots \\
{\left[\hat{w}_{n 1} ; \hat{b}_{n 1}\right]} & {\left[\hat{w}_{n 2} ; \hat{b}_{n 2}\right]} & \ldots & {\left[\hat{w}_{n m} ; \hat{b}_{n m}\right]}
\end{array}\right] .}
\end{gathered}
$$

Step 7: Calculating the sums $P_{i}$ of the attribute values, whose larger values are more preferable, for each alternative:

$$
P_{i}=\frac{1}{2} \sum_{j=1}^{k}\left(\hat{w}_{i j}+\hat{b}_{i j}\right) .
$$

Step 8: Calculating the sums $R_{i}$ of attribute values, whose smaller values are more preferable, for each alternative:

$$
R_{i}=\frac{1}{2} \sum_{j=k+1}^{m}\left(\hat{w}_{i j}+\hat{b}_{i j}\right) .
$$

In formula (22), $(m-k)$ is the number of attributes which must be minimized.

The sum of all $R_{i}$ and $P_{i}$ equals 1.

$$
\sum_{i=1}^{n} P_{i}+\sum_{i=1}^{n} R_{i}=1
$$

Step 9: Calculating the relative weight of each alternative $Q_{i}$ :

$$
Q_{i}=P_{i}+\frac{\sum_{i=1}^{n} R_{i}}{R_{i} \sum_{i=1}^{n} \frac{1}{R_{i}}} .
$$

Step 9*: If all attributes should be minimized then $P_{i}=0$ and $\sum_{j=1}^{n} R_{i}=1$. The formula (24) can by written as follows:

$$
Q_{i}=\frac{1}{R_{i} \cdot \sum_{i=1}^{n} \frac{1}{R_{i}}} .
$$

Step 10: Determining the optimality criterion $L$ :

$$
L=\max _{i} Q_{i} ; i=\overline{1, n} \text {. }
$$

Step 11: Determining the priority of the project.

Step 12: Calculating the utility degree of each alternative:

$$
N_{i}=\frac{Q_{i}}{L} .
$$

\subsection{Establishing the general solution}

There are two different multi-attribute decision-making methods presented: TOPSIS grey and COPRAS-G. Solution results for the problem under investigation are obtained compared to solution results and generated aggregated results of problem solution.

\section{Case study: risk assessment of construction projects}

Application of different solution methods sometimes yields different results. It is recommended to use several multi-attribute decision making methods for real problem solution and compare the results.

Due to a lack of information the attributes were determined at intervals. The TOPSIS method with attributes values determined at intervals and COPRAS-G 
method were applied to construction objects risk assessment of small-scale objects in construction. Risk assessment of four small-scale objects was made by 3 experts. The small-scale objects are of different design, architecture, construction technology, area, different number of floors and they are in different sites of the Vilnius region.

The initial decision making data are presented in Table 1 . In Table $1 q_{j}$ is the attribute weight and alternative objects are $v_{1}, \ldots, v_{4}$.

To determine the weights of the attributes, the experts' judgment method is applied (Kendall 1970), which has been successfully used in research by the authors since 1987 (Zavadskas 1987). In order to establish the weights, a survey has been carried out and 43 experts have been questioned. These experts, basing their answers on their knowledge, experience and intuition, had to rate attributes of effectiveness starting with the most important ones. The rating was done on a scale from 1 to 13 , where 13 meant "very important" and 1 "not important at all". The weights of attributes were established according to the rating methods (Zavadskas 1987) of these experts and also demonstrated the priorities of the user (stakeholder). The weights of the attributes obtained by this method are presented in Table 1. All risks in construction should be as minimal as possible - optimization direction is minimum. In Table 1 data on the following attributes are presented:

a) External risk assessment:

$$
\begin{aligned}
& \otimes x_{1}-\text { political, } \\
& \otimes x_{2} \text { - economic, }
\end{aligned}
$$

$\otimes x_{3}-$ social,

$\otimes x_{4}-$ weather;

b) Project risk assessment:

$\otimes x_{5}$ - time,

$\otimes x_{6}-$ cost,

$\otimes x_{7}-$ quality,

$\otimes x_{8}$ - technological,

$\otimes x_{9}-$ construction;

c) Internal risk assessment:

$$
\begin{aligned}
& \otimes x_{10}-\text { resource, } \\
& \otimes x_{11}-\text { project member, } \\
& \otimes x_{12}-\text { site, } \\
& \otimes x_{13}-\text { documents and information. }
\end{aligned}
$$

Each attribute is given zero to ten score. Every expert is allowed to give grey number evaluations.

In Table 2 the normalised decision-making matrix is presented with value of each attribute expressed at intervals, for the calculation of both: TOPSIS grey and COPRAS-G methods. Fig. 6 is a graphic view showing the calculation results according to TOPSIS grey method. The calculation results according to COPRAS-G method are presented in Fig. 7. Fig. 8 is a graphic view showing the aggregated results.

The calculation results for each project are presented in Table 3.

Overall least risk according to calculation results by applying TOPSIS grey method (Table 3 ) ranks as follows:

Project $1 \succ$ Project $3 \succ$ Project $4 \succ$ Project 2 .

Table 1. Initial decision-making matrix with values at some intervals

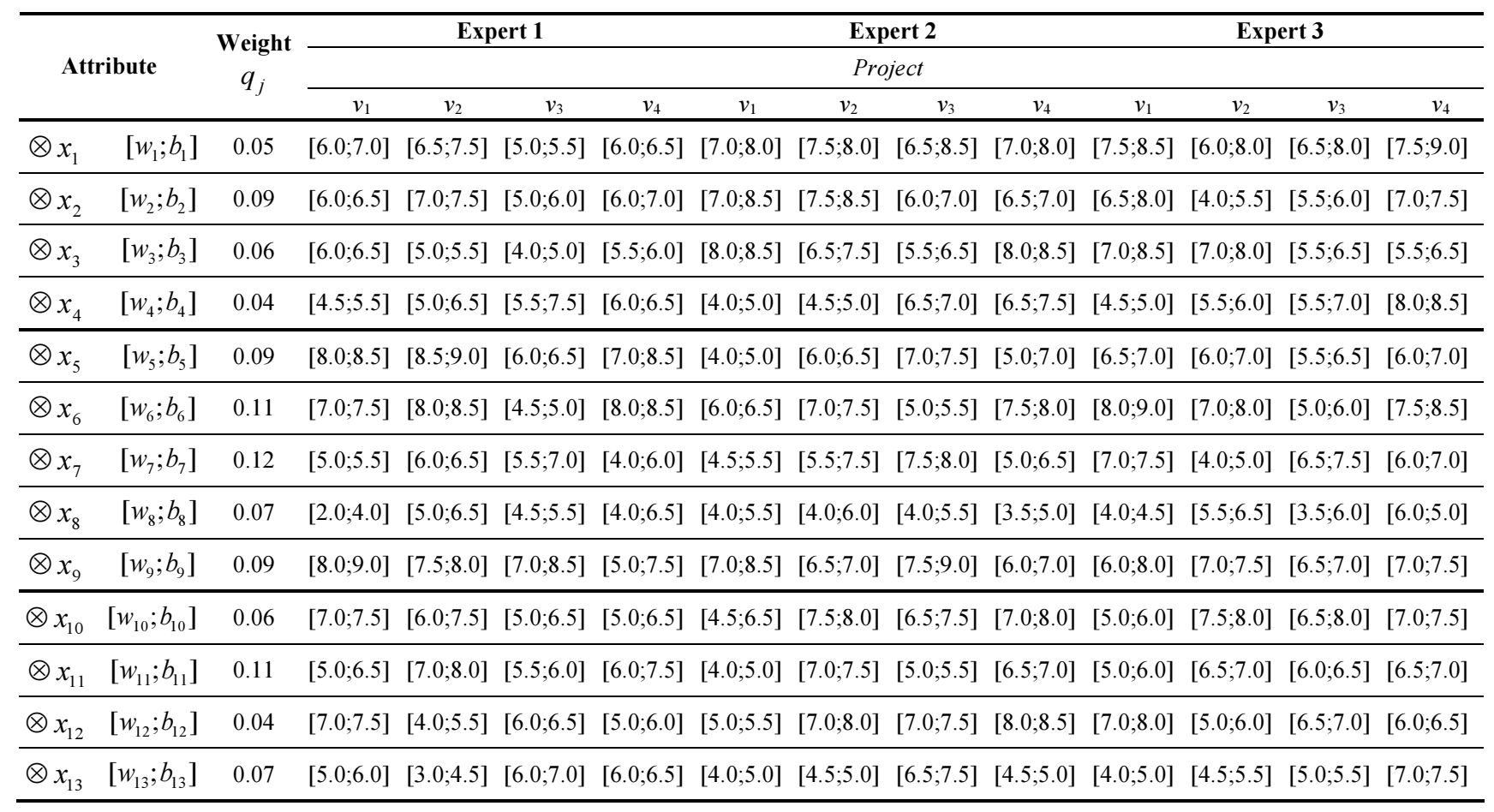




\begin{tabular}{|c|c|c|c|c|c|c|c|c|c|c|c|c|c|}
\hline \multirow{2}{*}{\multicolumn{2}{|c|}{ Attribute }} & \multicolumn{4}{|c|}{ Expert 1 } & \multirow{2}{*}{\multicolumn{4}{|c|}{$\begin{array}{c}\text { Expert 2 } \\
\text { Project }\end{array}$}} & \multicolumn{4}{|c|}{ Expert 3} \\
\hline & & & & & & & & & & & & & \\
\hline & & $v_{1}$ & $v_{2}$ & $v_{3}$ & $v_{4}$ & $v_{1}$ & $v_{2}$ & $v_{3}$ & $v_{4}$ & $v_{1}$ & $v_{2}$ & $v_{3}$ & $v_{4}$ \\
\hline & & & & & & & TOPSIS gr & $y$ method & & & & & \\
\hline$\otimes \bar{x}_{1}$ & {$\left[\bar{w}_{1} ; \bar{b}_{1}\right]$} & {$[0.80 ; 0.60]$} & {$[0.92 ; 0.50]$} & {$[1.00 ; 0.90]$} & {$[0.80 ; 0.70]$} & {$[0.92 ; 0.77]$} & {$[0.85 ; 0.92]$} & {$[1.00 ; 0.69]$} & {$[0.92 ; 0.77]$} & {$[0.75 ; 0.58]$} & {$[1.00 ; 0.67]$} & {$[0.92 ; 0.67]$} & {$[0.75 ; 0.50]$} \\
\hline$\otimes \bar{x}_{2}$ & {$\left[\bar{w}_{2} ; \bar{b}_{2}\right]$} & {$[0.80 ; 0.70]$} & {$[0.60 ; 0.50]$} & {$[1.00 ; 0.80]$} & {$[0.80 ; 0.60]$} & {$[0.83 ; 0.67]$} & {$[0.75 ; 0.58]$} & {$[1.00 ; 0.83]$} & {$[0.92 ; 0.83]$} & {$[0.38 ; 0.13]$} & {$[1.00 ; 0.63]$} & {$[0.63 ; 0.50]$} & {$[0.25 ; 0.13]$} \\
\hline$\otimes \bar{x}_{3}$ & {$\left[\bar{w}_{3} ; \bar{b}_{3}\right]$} & {$[0.50 ; 0.38]$} & {$[0.75 ; 0.63]$} & {$[1.00 ; 0.75]$} & {$[0.63 ; 0.50]$} & {$[0.55 ; 0.45]$} & {$[0.82 ; 0.64]$} & {$[1.00 ; 0.82]$} & {$[0.55 ; 0.45]$} & {$[0.60 ; 0.30]$} & {$[0.60 ; 0.40]$} & {$[1.00 ; 0.70]$} & {$[0.90 ; 0.70]$} \\
\hline$\otimes \bar{x}_{4}$ & {$\left[\bar{w}_{4} ; \bar{b}_{4}\right]$} & {$[1.00 ; 0.78]$} & {$[0.89 ; 0.56]$} & {$[0.78 ; 0.73]$} & {$[0.67 ; 0.78]$} & {$[1.00 ; 0.75]$} & {$[0.88 ; 0.75]$} & {$[0.38 ; 0.25]$} & {$[0.38 ; 0.13]$} & {$[1.00 ; 0.89]$} & {$[0.78 ; 0.67]$} & {$[0.78 ; 0.44]$} & {$[0.22 ; 0.11]$} \\
\hline$\otimes \bar{x}_{5}$ & {$\left[\bar{w}_{5} ; \bar{b}_{5}\right]$} & {$[0.67 ; 0.58]$} & {$[0.58 ; 0.50]$} & {$[1.00 ; 0.92]$} & {$[0.83 ; 0.58]$} & {$[1.00 ; 0.75]$} & {$[0.50 ; 0.38]$} & {$[0.25 ; 0.13]$} & {$[0.75 ; 0.25]$} & {$[0.82 ; 0.73]$} & {$[0.91 ; 0.64]$} & {$[1.00 ; 0.82]$} & {$[0.91 ; 0.73]$} \\
\hline$\otimes \bar{x}_{6}$ & {$\left[\bar{w}_{6} ; \bar{b}_{6}\right]$} & {$[0.44 ; 0.33]$} & {$[0.33 ; 0.11]$} & {$[1.00 ; 0.89]$} & {$[0.44 ; 0.11]$} & {$[0.80 ; 0.70]$} & {$[0.60 ; 0.50]$} & {$[0.55 ; 0.90]$} & {$[0.50 ; 0.40]$} & {$[0.40 ; 0.20]$} & {$[0.60 ; 0.40]$} & {$[1.00 ; 0.80]$} & {$[0.50 ; 0.30]$} \\
\hline$\otimes \bar{x}_{7}$ & {$\left[\bar{w}_{7} ; \bar{b}_{7}\right]$} & {$[0.75 ; 0.63]$} & {$[0.50 ; 0.38]$} & {$[0.63 ; 0.25]$} & {$[1.00 ; 0.50]$} & {$[1.00 ; 0.78]$} & {$[0.78 ; 0.33]$} & {$[0.33 ; 0.22]$} & {$[0.89 ; 0.56]$} & {$[0.25 ; 0.13]$} & {$[1.00 ; 0.75]$} & {$[0.38 ; 0.13]$} & {$[0.50 ; 0.25]$} \\
\hline$\otimes \bar{x}_{8}$ & {$\left[\bar{w}_{8} ; \bar{b}_{8}\right]$} & {$[1.00 ; 0.86]$} & {$[0.57 ; 0.14]$} & {$[0.71 ; 0.43]$} & {$[0.86 ; 0.14]$} & {$[0.86 ; 0.43]$} & {$[0.86 ; 0.29]$} & {$[0.86 ; 0.43]$} & {$[1.00 ; 0.57]$} & {$[0.86 ; 0.71]$} & {$[0.43 ; 0.14]$} & {$[1.00 ; 0.29]$} & {$[0.29 ; 0.57]$} \\
\hline$\otimes \bar{x}_{9}$ & {$\left[\bar{w}_{9} ; \bar{b}_{9}\right]$} & {$[0.40 ; 0.20]$} & {$[0.50 ; 0.40]$} & {$[0.60 ; 0.30]$} & {$[1.00 ; 0.50]$} & {$[0.83 ; 0.58]$} & {$[0.92 ; 0.83]$} & {$[0.75 ; 0.50]$} & {$[0.80 ; 0.82]$} & {$[1.00 ; 0.67]$} & {$[0.83 ; 0.75]$} & {$[0.92 ; 0.83]$} & {$[0.83 ; 0.75]$} \\
\hline$\otimes \bar{x}_{10}$ & {$\left[\bar{w}_{10} ; \bar{b}_{10}\right]$} & {$[0.60 ; 0.40]$} & {$[0.80 ; 0.50]$} & {$[1.00 ; 0.70]$} & {$[0.80 ; 0.70]$} & {$[1.00 ; 0.56]$} & {$[0.33 ; 0.22]$} & {$[0.56 ; 0.33]$} & {$[0.44 ; 0.22]$} & {$[1.00 ; 0.80]$} & {$[0.50 ; 0.30]$} & {$[0.70 ; 0.40]$} & {$[0.60 ; 0.50]$} \\
\hline$\otimes \bar{x}_{11}$ & {$\left[\bar{w}_{11} ; \bar{b}_{11}\right]$} & {$[1.00 ; 0.70]$} & {$[0.60 ; 0.40]$} & {$[0.90 ; 0.80]$} & {$[0.80 ; 0.50]$} & {$[1.00 ; 0.75]$} & {$[0.25 ; 0.13]$} & {$[0.75 ; 0.63]$} & {$[0.38 ; 0.25]$} & {$[1.00 ; 0.80]$} & {$[0.70 ; 0.60]$} & {$[0.80 ; 0.70]$} & {$[0.70 ; 0.60]$} \\
\hline$\otimes \bar{x}_{12}$ & {$\left[\bar{w}_{12} ; \bar{b}_{12}\right]$} & {$[0.25 ; 0.13]$} & {$[1.00 ; 0.63]$} & {$[0.50 ; 0.38]$} & {$[0.86 ; 0.50]$} & {$[1.00 ; 0.90]$} & {$[0.60 ; 0.40]$} & {$[0.60 ; 0.50]$} & {$[0.40 ; 0.30]$} & {$[0.60 ; 0.40]$} & {$[1.00 ; 0.80]$} & {$[0.70 ; 0.60]$} & {$[0.80 ; 0.70]$} \\
\hline$\otimes \bar{x}_{13}$ & {$\left[\bar{w}_{13} ; \bar{b}_{13}\right]$} & {$[0.75 ; 0.50]$} & {$[1.00 ; 0.88]$} & {$[0.38 ; 0.25]$} & {$[0.50 ; 0.38]$} & {$[1.00 ; 0.75]$} & {$[0.88 ; 0.75]$} & {$[0.38 ; 0.13]$} & {$[0.88 ; 0.75]$} & {$[1.00 ; 0.75]$} & {$[0.88 ; 0.63]$} & {$[0.75 ; 0.63]$} & {$[0.25 ; 0.13]$} \\
\hline & & & & & & COPRAS & method & & & & & & \\
\hline$\otimes \bar{x}_{1}$ & {$\left[\bar{w}_{1} ; \bar{b}_{1}\right]$} & {$[0.24 ; 0.28]$} & {$[0.26 ; 0.30]$} & {$[0.20 ; 0.22]$} & {$[0.24 ; 0.26]$} & {$[0.23 ; 0.26]$} & {$[0.25 ; 0.26]$} & {$[0.21 ; 0.28]$} & {$[0.23 ; 0.26]$} & {$[0.25 ; 0.28]$} & {$[0.20 ; 0.26]$} & {$[0.21 ; 0.26]$} & {$[0.25 ; 0.30]$} \\
\hline$\otimes \bar{x}_{2}$ & {$\left[\bar{w}_{2} ; \bar{b}_{2}\right]$} & {$[0.24 ; 0.25]$} & {$[0.27 ; 0.29]$} & {$[0.20 ; 0.24]$} & {$[0.24 ; 0.27]$} & {$[0.24 ; 0.28]$} & {$[0.26 ; 0.30]$} & {$[0.21 ; 0.24]$} & {$[0.23 ; 0.24]$} & {$[0.26 ; 0.30]$} & {$[0.16 ; 0.22]$} & {$[0.22 ; 0.24]$} & {$[0.28 ; 0.30]$} \\
\hline$\otimes \bar{x}_{3}$ & {$\left[\bar{w}_{3} ; \bar{b}_{3}\right]$} & {$[0.28 ; 0.30]$} & {$[0.23 ; 0.25]$} & {$[0.18 ; 0.23]$} & {$[0.25 ; 0.28]$} & {$[0.27 ; 0.29]$} & {$[0.22 ; 0.25]$} & {$[0.19 ; 0.22]$} & {$[0.27 ; 0.29]$} & {$[0.26 ; 0.31]$} & {$[0.26 ; 0.30]$} & {$[0.19 ; 0.24]$} & {$[0.20 ; 0.24]$} \\
\hline$\otimes \bar{x}_{4}$ & {$\left[\bar{w}_{4} ; \bar{b}_{4}\right]$} & {$[0.19 ; 0.23]$} & {$[0.21 ; 0.28]$} & {$[0.23 ; 0.32]$} & {$[0.26 ; 0.28]$} & {$[0.17 ; 0.22]$} & {$[0.20 ; 0.22]$} & {$[0.28 ; 0.30]$} & {$[0.28 ; 0.33]$} & {$[0.18 ; 0.20]$} & {$[0.22 ; 0.24]$} & {$[0.22 ; 0.28]$} & {$[0.32 ; 0.34]$} \\
\hline$\otimes \bar{x}_{5}$ & {$\left[\bar{w}_{5} ; \bar{b}_{5}\right]$} & {$[0.26 ; 0.27]$} & {$[0.27 ; 0.29]$} & {$[0.19 ; 0.21]$} & {$[0.23 ; 0.27]$} & {$[0.17 ; 0.21]$} & {$[0.25 ; 0.27]$} & {$[0.29 ; 0.31]$} & {$[0.21 ; 0.29]$} & {$[0.25 ; 0.27]$} & {$[0.23 ; 0.29]$} & {$[0.21 ; 0.25]$} & {$[0.23 ; 0.27]$} \\
\hline$\otimes \bar{x}_{6}$ & {$\left[\bar{w}_{6} ; \bar{b}_{6}\right]$} & {$[0.25 ; 0.27]$} & {$[0.27 ; 0.31]$} & {$[0.16 ; 0.18]$} & {$[0.25 ; 0.31]$} & {$[0.23 ; 0.25]$} & {$[0.26 ; 0.28]$} & {$[0.19 ; 0.21]$} & {$[0.28 ; 0.30]$} & {$[0.27 ; 0.31]$} & {$[0.24 ; 0.27]$} & {$[0.17 ; 0.20]$} & {$[0.25 ; 0.29]$} \\
\hline$\otimes \bar{x}_{7}$ & {$\left[\bar{w}_{7} ; \bar{b}_{7}\right]$} & {$[0.22 ; 0.24]$} & {$[0.26 ; 0.29]$} & {$[0.24 ; 0.31]$} & {$[0.18 ; 0.26]$} & {$[0.18 ; 0.22]$} & {$[0.22 ; 0.30]$} & {$[0.30 ; 0.32]$} & {$[0.20 ; 0.26]$} & {$[0.28 ; 0.30]$} & {$[0.16 ; 0.20]$} & {$[0.26 ; 0.30]$} & {$[0.24 ; 0.28]$} \\
\hline$\otimes \bar{x}_{8}$ & {$\left[\bar{w}_{8} ; \bar{b}_{8}\right]$} & {$[0.18 ; 0.20]$} & {$[0.25 ; 0.33]$} & {$[0.23 ; 0.28]$} & {$[0.20 ; 0.33]$} & {$[0.21 ; 0.29]$} & {$[0.21 ; 0.32]$} & {$[0.21 ; 0.29]$} & {$[0.19 ; 0.27]$} & {$[0.20 ; 0.22]$} & {$[0.27 ; 0.32]$} & {$[0.17 ; 0.29]$} & {$[0.24 ; 0.29]$} \\
\hline$\otimes \bar{x}_{9}$ & {$\left[\bar{w}_{9} ; \bar{b}_{9}\right]$} & {$[0.26 ; 0.30]$} & {$[0.25 ; 0.26]$} & {$[0.23 ; 0.28]$} & {$[0.17 ; 0.25]$} & {$[0.24 ; 0.29]$} & {$[0.22 ; 0.24]$} & {$[0.26 ; 0.31]$} & {$[0.21 ; 0.24]$} & {$[0.21 ; 0.28]$} & {$[0.25 ; 0.27]$} & {$[0.23 ; 0.25]$} & {$[0.25 ; 0.27]$} \\
\hline$\otimes \bar{x}_{10}$ & {$\left[\bar{w}_{10} ; \bar{b}_{10}\right]$} & {$[0.27 ; 0.30]$} & {$[0.23 ; 0.29]$} & {$[0.19 ; 0.25]$} & {$[0.23 ; 0.25]$} & {$[0.16 ; 0.23]$} & {$[0.27 ; 0.29]$} & {$[0.23 ; 0.27]$} & {$[0.25 ; 0.29]$} & {$[0.18 ; 0.21]$} & {$[0.27 ; 0.30]$} & {$[0.23 ; 0.29]$} & {$[0.25 ; 0.27]$} \\
\hline$\otimes \bar{x}_{11}$ & {$\left[\bar{w}_{11} ; \bar{b}_{11}\right]$} & {$[0.19 ; 0.25]$} & {$[0.27 ; 0.31]$} & {$[0.21 ; 0.23]$} & {$[0.23 ; 0.29]$} & {$[0.17 ; 0.21]$} & {$[0.29 ; 0.32]$} & {$[0.21 ; 0.23]$} & {$[0.27 ; 0.29]$} & {$[0.20 ; 0.24]$} & {$[0.26 ; 0.28]$} & {$[0.24 ; 0.26]$} & {$[0.26 ; 0.28]$} \\
\hline$\otimes \bar{x}_{12}$ & {$\left[\bar{w}_{12} ; \bar{b}_{12}\right]$} & {$[0.29 ; 0.32]$} & {$[0.17 ; 0.23]$} & {$[0.25 ; 0.27]$} & {$[0.21 ; 0.25]$} & {$[0.18 ; 0.19]$} & {$[0.25 ; 0.28]$} & {$[0.25 ; 0.27]$} & {$[0.28 ; 0.30]$} & {$[0.27 ; 0.31]$} & {$[0.19 ; 0.23]$} & {$[0.25 ; 0.27]$} & {$[0.23 ; 0.25]$} \\
\hline$\otimes \bar{x}_{13}$ & {$\left[\bar{w}_{13} ; \bar{b}_{13}\right]$} & {$[0.22 ; 0.26]$} & {$[0.18 ; 0.20]$} & {$[0.29 ; 0.31]$} & {$[0.26 ; 0.29]$} & {$[0.19 ; 0.24]$} & {$[0.21 ; 0.24]$} & {$[0.31 ; 0.36]$} & {$[0.21 ; 0.24]$} & {$[0.18 ; 0.23]$} & {$[0.20 ; 0.25]$} & {$[0.23 ; 0.25]$} & {$[0.32 ; 0.34]$} \\
\hline
\end{tabular}


Table 3. Solution results by applying TOPSIS grey and COPRAS-G methods

\begin{tabular}{|c|c|c|c|c|c|c|c|c|c|c|c|}
\hline \multirow{6}{*}{$\begin{array}{l}\text { Calculation results by } \\
\text { applying TOPSIS grey } \\
\text { method }\end{array}$} & & \multicolumn{2}{|c|}{ Expert 1} & \multicolumn{2}{|c|}{ Expert 2} & \multicolumn{2}{|c|}{ Expert 3} & \multicolumn{2}{|c|}{ Aggregated } & \multirow{2}{*}{$C_{i}^{*+}$} & \multirow{2}{*}{ Rank } \\
\hline & & $d^{1+}$ & $d^{1-}$ & $d^{2+}$ & $d^{2-}$ & $d^{3+}$ & $d^{3-}$ & $d^{*+}$ & $d^{*_{-}}$ & & \\
\hline & $v_{1}$ & 0.449 & 0.510 & 0.489 & 0.637 & 0.513 & 0.385 & 0.484 & 0.511 & 0.514 & 1 \\
\hline & $v_{2}$ & 0.532 & 0.307 & 0.725 & 0.318 & 0.387 & 0.448 & 0.548 & 0.358 & 0.395 & 4 \\
\hline & $v_{3}$ & 0.379 & 0.447 & 0.503 & 0.402 & 0.393 & 0.421 & 0.425 & 0.423 & 0.499 & 2 \\
\hline & $v_{4}$ & 0.496 & 0.438 & 0.493 & 0.555 & 0.520 & 0.224 & 0.503 & 0.406 & 0.446 & 3 \\
\hline \multirow{5}{*}{$\begin{array}{l}\text { Calculation results by } \\
\text { applying COPRAS-G } \\
\text { method }\end{array}$} & & \multicolumn{2}{|c|}{$N^{1}$} & \multicolumn{2}{|c|}{$N^{2}$} & \multicolumn{2}{|c|}{$N^{3}$} & \multicolumn{2}{|c|}{$N^{A}$} & & Rank \\
\hline & $v_{1}$ & \multicolumn{2}{|c|}{0.931} & \multicolumn{2}{|c|}{1.000} & \multicolumn{2}{|c|}{0.946} & \multicolumn{2}{|c|}{0.959} & & 1 \\
\hline & $v_{2}$ & \multicolumn{2}{|c|}{0.877} & \multicolumn{2}{|c|}{0.857} & \multicolumn{2}{|c|}{0.984} & \multicolumn{2}{|c|}{0.906} & & 3 \\
\hline & $v_{3}$ & \multicolumn{2}{|c|}{1.000} & \multicolumn{2}{|c|}{0.865} & \multicolumn{2}{|c|}{1.000} & \multicolumn{2}{|c|}{0.955} & & 2 \\
\hline & $v_{4}$ & \multicolumn{2}{|c|}{0.931} & \multicolumn{2}{|c|}{0.877} & \multicolumn{2}{|c|}{0.883} & \multicolumn{2}{|c|}{0.897} & & 4 \\
\hline
\end{tabular}

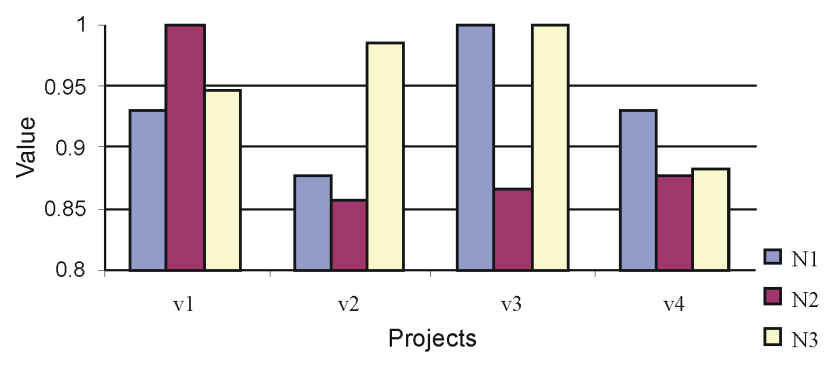

Fig. 6. Calculation results according to COPRAS-G method

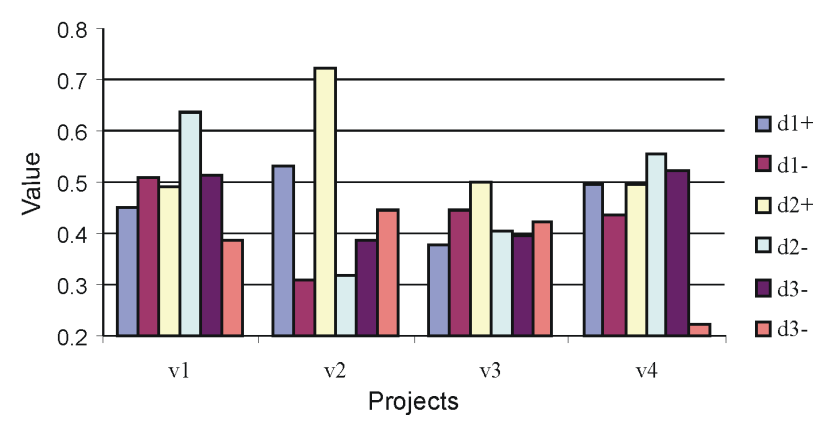

Fig.7. Calculation results according to TOPSIS grey method

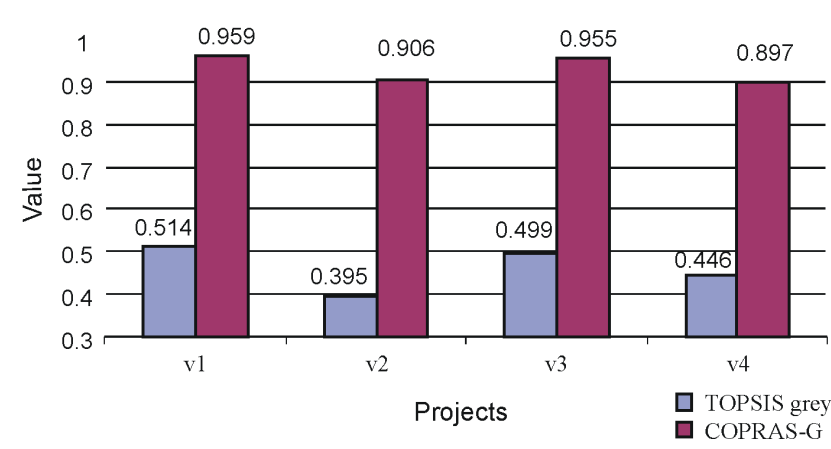

Fig. 8. Aggregated calculation results (COPRAS-G and TOPSIS grey methods)
The projects risk according to COPRAS-G method ranks as follows:

Project $1 \succ$ Project $3 \succ$ Project $2 \succ$ Project 4 .

The calculation results showed that the first project has the least risk and the second or the fourth project are most risky. The first alternative was selected and implemented.

\section{Conclusions}

Decision-making is very important in the construction management, such as risk assessment results in construction projects, contractor and supplier selection, etc.

In real life multi-attribute modelling of multialternative assessment problems have some attribute values, which deal with the future and must be expressed at intervals.

Sometimes calculation according to different methods yields different results. For decision-making it is reasonable to apply several methods and select the best alternative according to aggregated results.

This model and solution results are of both practical and scientific interest. It allows all members of the construction business to make a decision by evaluating multiple attributes when values of initial data are given at intervals.

The research results show the different risk levels of construction objects.

\section{References}

Albert, I.; Grenier, E.; Denis, J.-B.; Rousseau, J. 2008. Quantitative risk assessment from farm to fork and beyond: a global bayesian approach concerning food-borne diseases, Risk Analysis 28(2): 557-571. doi:10.1111/j.1539-6924.2008.01000.x

Aniūnas, P.; Nedzveckas, J.; Krušinskas, R. 2009. Variance covariance risk value model for currency market, Inzinerine Ekonomika - Engineering Economics 1: 18-27.

Banaitienè, N.; Banaitis, A.; Kaklauskas, A.; Zavadskas, E. K. 2008. Evaluating the life cycle of building: A multivariant and multiple criteria approach, Omega - International Journal of Management Science 36(3): 429-441. doi:10.1016/j.omega.2005.10.010 
Brauers, W. K.; Zavadskas, E. K.; Peldschus, F.; Turskis, Z. 2008a. Multi-objective decision-making for road design, Transport 23(3): 183-192. doi:10.3846/1648-4142.2008.23.183-193

Brauers, W. K.; Zavadskas, E. K.; Turskis, Z.; Vilutienė, T. 2008b. Multi-objective contractor's ranking by applying the MOORA method, Journal of Business Economics and Management 9(4): 245-255. doi:10.3846/1611-1699.2008.9.245-255

Brauers, W. K. M.; Ginevicius, R.; Zavadskas, E. K.; Antucheviciene, J. 2007. The European Union in a transition economy, Transformation in Business and Economy 6(2): 21-37.

Brauers, W. K.; Zavadskas, E. K. 2006. The MOORA method and its application to privatization in a transition economy, Control and Cybernetics 35(2): 443-468.

Bregar, A.; Györkös, J.; Jurič, M. B. 2008. Interactive aggregation/disaggregation dichotomic sorting procedure for group decision analysis based on the threshold model, Informatica 19(2): 161-190.

Cakir, O. 2008. The grey extent analysis, Kybernetes 37(7): 997-1015. doi:10.1108/03684920810884379

Conchie, S. M.; Burns, C. 2008. Trust and risk communication in high-risk organizations: a test of principles from social risk research, Risk Analysis 28(1): 141-149. doi:10.1111/j.1539-6924.2008.01006.x

Deng, J. L. 1982. Control problems of grey system, Systems and Control Letters 1(5): 288-294. doi:10.1016/S0167-6911(82)80025-X

Deng, J. L. 1988. Properties of relational space for grey system, in Essential Topics on Grey System - Theory and Applications (J. L. Deng, Ed.). Beijing: China Ocean, 1-13.

Deng, J. L. 1989. Introduction to grey system theory, The Journal of Grey System 1(1): 1-24.

Dikmen, I.; Birgonul, M. T.; Anac, C.; Tah, J. H. M.; Aouad, G. 2008. Learning from risks: a tool for post-project risk assessment, Automation in Construction 18(1): 42-50. doi:10.1016/j.autcon.2008.04.008

Dytczak, M.; Ginda, G. 2009. Identification of building repair policy choice criteria role, Technological and Economic Development of Economy 15(2): 213-228. doi:10.3846/1392-8619.2009.15.213-228

Dzemyda, G.; Šaltenis, V.; Tiešis, V. 2007. Optimizavimo metodai [Optimization Methods]. Vilnius: Mokslo aidai (in Lithuanian).

El-Sayegh, S. M. 2008. Risk assessment and allocation in the UAE construction industry, International Journal of Project Management 26(4): 431-438. doi:10.1016/j.ijproman.2007.07.004

Figueira, J.; Greco, S.; Ehrgott, M. (Eds.). 2005. Multiple Criteria Decision Analysis: State of the Art Surveys. Springer, Berlin.

Fisk, E. R. 2003. Construction Project Administration. Seventh Edition. Prentice Hall Upper Saddle River, New Jersey Columbus, Ohio.

Gao, P.-W. 2009. Options strategies with the risk adjustment, European Journal of Operational Research 192(3): 975980. doi:10.1016/j.ejor.2007.10.010

Ginevičius, R.; Podvezko, V. 2009. Evaluating the changes in economic and social development of Lithuanian counties by multiple criteria methods, Technological and Economic Development of Economy 15(3): 418-436. doi:10.3846/1392-8619.2009.15.418-436

Ginevičius, R. 2008. Normalization of quantities of various dimensions, Journal of Business Economics and Management 9(1): 79-86. doi:10.3846/1611-1699.2008.9.79-86
Ginevičius, R.; Krivka, A. 2008. Application of game theory for duopoly market analysis, Journal of Business Economics and Management 9(3): 207-217. doi:10.3846/1611-1699.2008.9.207-217

Ginevičius, R.; Podvezko, V.; Bruzgè, Š. 2008a. Evaluating the effect of state aid to business by multicriteria methods, Journal of Business Economics and Management 9(3): 167-180. doi:10.3846/1611-1699.2008.9.167-180

Ginevičius, R.; Podvezko, V.; Raslanas, S. 2008b. Evaluating the alternative solutions of wall insulation by multicriteria methods, Journal of Civil Engineering and Management 14(4): 217-226. doi:10.3846/1392-3730.2008.14.20

Ginevicius, R.; Podvezko, V.; Andruskevicius, A. 2007. Quantitative evaluation of building technology, International Journal of Technology Management 40(1/2/3): 192-214.

Graves, S. B.; Ringuest, J. L. 2009. Probabilistic dominance criteria for comparing uncertain alternatives: A tutorial, Omega - International Journal of Management Science 37(2): 346-357. doi:10.1016/j.omega.2007.03.001

Gunstone, S. 2003. Risk assessment and management of patients whom self-neglect: a 'grey area' for mental health workers, Journal of Psychiatric and Mental Health Nursing 10(3): 287-296. doi:10.1046/j.1365-2850.2003.00568.x

Han, S. H.; Kim, D. Y.; Kim, H.; Jang, W.-S. 2008. A webbased integrated system for international project risk management, Automation in Construction 17(3): 342356. doi:10.1016/j.autcon.2007.05.012

Hassanein, A. A. G.; Afify, H. M. F. 2007. A risk identification procedure for construction contracts-a case study of power station projects in Egypt, Civil Engineering and Environmental Systems 24(1): 3-14. doi:10.1080/10286600600910104

Hwang, C. L.; Yoon, K. S. 1981. Multiple Attribute Decision Making Methods and Applications. Springer-Verlag. Berlin, Heidelberg, New York.

Isaac, S.; Navon, R. 2009. Modeling building projects as a basis for change control, Automation in Construction 18(5): 656-664. doi:10.1016/j.autcon.2009.01.001

Jakimavicius, M.; Burinskiene, M. 2009a. Assessment of Vilnius city development scenarios based on transport system modelling and multicriteria analysis, Journal of Civil Engineering and Management 15(4): 361-368. doi:10.3846/1392-3730.2009.15.361-368

Jakimavičius, M.; Burinskienè, M. 2009b. A GIS and multicriteria-based analysis and ranking of transportation zones of Vilnius city, Technological and Economic Development of Economy 15(1): 39-48. doi:10.3846/1392-8619.2009.15.39-48

Kalibatas, D.; Turskis, Z. 2008. Multicriteria evaluation of inner climate by using MOORA method, Information Technology and Control 37(1): 79-83.

Kaklauskas, A.; Zavadskas, E. K.; Trinkūnas, V. 2007. A multiple criteria decision support online system for construction, Engineering Applications of Artificial Intelligence 20(2): 163-175. doi:10.1016/j.engappai.2006.06.009

Kendall, M. G. 1970. Rank Correlation Methods. 4th ed. London Griffin.

Kuo, Y.; Yang, T.; Huang, G.-W. 2008. The use of grey relational analysis in solving multiple attribute decisionmaking problems, Computers \& Industrial Engineering 55(1): 80-93. doi:10.1016/j.cie.2007.12.002

Lahdelma, R.; Makkonen, S.; Salminen, P. 2009. Two ways to handle dependent uncertainties in multi-criteria decision problems, Omega - International Journal of Management Science 37: 79-92. doi:10.1016/j.omega.2006.08.005 
Li, Y.; Liao, X. 2007. Decision support for risk analysis on dynamic alliance, Decision Support Systems 42(4): 2043 2059. doi:10.1016/j.dss.2004.11.008

Li, G.-D.; Yamaguchi, D.; Nagai, M. 2007. A grey-based decision-making approach to the supplier selection problem, Mathematical and Computer Modelling 46(3-4): 573581. doi:10.1016/j.mcm.2006.11.021

Liaudanskiene, R.; Ustinovicius, L.; Bogdanovicius, A. 2009. Evaluation of construction process safety solutions using the TOPSIS method, Inzinerine Ekonomika - Engineering Economics (4): 32-40.

Lin, Y.; Liu, S. 2007. National economic strength as evaluated using grey systems theory, Kybernetes 36(1): 89-97. doi:10.1108/03684920710741170

Lin, Y.-H.; Lee, P.-C.; Chang, T.-P.; Ting, H.-I. 2008. Multiattribute group decision making model under the condition of uncertain information, Automation in Construction 17(6): 792-797. doi:10.1016/j.autcon.2008.02.011

Liu, P. 2009. Multi-attribute decision-making research method based on interval vague set and TOPSIS method, Technological and Economic Development of Economy 15(3): 453-463. doi:10.3846/1392-8619.2009.15.453-463

Mitkus, S.; Šostak, O. R. 2008. Modelling the process for defence of third party rights infringed while implementing construction investment projects, Technological and Economic Development of Economy 14(2): 208-223. doi:10.3846/1392-8619.2008.14.208-223

Mitkus, S.; Trinkuniene, E. 2008. Reasoned decisions in construction contracts evaluation, Technological and Economic Development of Economy 14(3): 402-416. doi:10.3846/1392-8619.2008.14.402-416

Opricovic, S.; Tzeng, G.-H. 2004. Compromise solution by MCDM methods: A comparative analysis of VIKOR and TOPSIS, European Journal of Operational Research 156(2): 445-455. doi:10.1016/S0377-2217(03)00020-1

Peldschus, F. 2009. The analysis of the quality of the results obtained with the methods of multi-criteria decisions, Technological and Economic Development of Economy 15(4): 580-592. doi:10.3846/1392-8619.2009.15.580-592

Peldschus, F. 2008. Experience of the game theory application in construction management, Technological and Economic Development of Economy 14(4): 531-545. doi:10.3846/1392-8619.2008.14.531-545

Perera, B. A. K. S.; Dhanasinghe, I.; Rameezdeen, R. 2009. Risk management in road construction: the case of Sri Lanka, International Journal of Strategic Property Management 13(2): 87-102. doi:10.3846/1648-715X.2009.13.87-102

Plebankiewicz, E. 2009. Contractor prequalification model using fuzzy sets, Journal of Civil Engineering and Management 15(4): 377-385.

doi:10.3846/1392-3730.2009.15.377-385

Podvezko, V. 2009. Application of AHP technique, Journal of Business Economics and Management 10(2): 181-189. doi:10.3846/1611-1699.2009.10.181-189

Project Management Institute Standards Committee. A Guide to the project management body of knowledge. 3 rd ed. PMI 2004.

Rutkauskas, A. V. 2008. On the sustainability of regional competitiveness development considering risk, Technological and Economic Development of Economy 14(1): 89-99. doi:10.3846/2029-0187.2008.14.89-99

Shen, V. R. L.; Chung, Y.-F.; Chen, T.-S. 2009. A novel application of grey system theory to information security.
Part I, Computer Standards \& Interfaces 31(2): 277-281. doi:10.1016/j.csi.2007.11.018

Shevchenko, G.; Ustinovichius, L.; Andruškevičius, A. 2008. Multi-attribute analysis of investments risk alternatives in construction, Technological and Economic Development of Economy 14(3): 428-443. doi:10.3846/1392-8619.2008.14.428-443

Shih, H.-S. 2008. Incremental analysis for MCDM with an application to group TOPSIS, European Journal of Operational Research 186(2): 720-734. doi:10.1016/j.ejor.2007.02.012

Shih, H.-S.; Shyur, H.-J.; Lee, E. S. 2007. An extension of TOPSIS for group decision making, Mathematical and Computer Modelling 45(7-8): 801-813. doi:10.1016/j.mcm.2006.03.023

Schieg, M. 2009. Model for integrated project management, Journal of Business Economics and Management 10(2): 149-160. doi:10.3846/1611-1699.2009.10.149-160

Schieg, M. 2008. Strategies for avoiding asymmetric information in construction project management, Journal of Business Economics and Management 9(1): 47-51. doi:10.3846/1611-1699.2008.9.47-51

Straub, A. 2009. Cost savings from performance-based maintenance contracting, International Journal of Strategic Property Management 13(3): 205-217. doi:10.3846/1648-715X.2009.13.205-217

Suhobokov, A. 2007. Application of Monte Carlo simulation methods in risk management, Journal of Business Economics and Management 8(3): 165-168.

Šarka, V.; Zavadskas, E. K.; Ustinovičius, L.; Šarkienė, E.; Ignatavičius, Č. 2008. System of project multicriteria decision synthesis in construction, Technological and Economic Development of Economy 14(4): 546-565. doi:10.3846/1392-8619.2008.14.546-565

Turskis, Z.; Zavadskas, E. K.; Peldschus, F. 2009. Multi-criteria optimization system for decision making in construction design and management, Inzinerine Ekonomika - Engineering Economics 1: 7-17.

Turskis, Z. 2008. Multi-attribute contractors ranking method by applying ordering of feasible alternatives of solutions in terms of preferability technique, Technological and Economic Development of Economy 14(2): 224-239. doi:10.3846/1392-8619.2008.14.224-239

Tvaronavičienè, M.; Grybaite, V. 2007. Impact of FDI on Lithuanian economy: insight into development of main economic activities, Journal of Business Economics and Management 8(4): 285-290.

Tserng, H. P.; Yin, S. Y. L.; Dzeng, R. J.; Wou, B.; Tsai, M. D.; Chen, W. Y. 2009. A study of ontology-based risk management framework of construction projects through project life cycle, Automation in Construction 18(7): 9941008. doi:10.1016/j.autcon.2009.05.005

Ulubeyli, S.; Kazaz, A. 2009. A multiple criteria decision making approach to the selection of concrete pumps, Journal of Civil Engineering and Management 15(4): 369-376. doi:10.3846/1392-3730.2009.15.369-376

Zayed, T.; Amer, M.; Pan, J. 2008. Assessing risk and uncertainty inherent in Chinese highway projects using AHP, International Journal of Project Management 26(4): 408419. doi:10.1016/j.ijproman.2007.05.012

Zavadskas, E. K.; Vilutiene, T.; Turskis, Z.; Tamosaitiene, J. 2010. Contractor selection for construction works by applying SAW-G and TOPSIS grey techniques, Journal of Business Economics and Management 11(1): 34-54. 
Zavadskas, E. K.; Kaklauskas, A.; Turskis, Z.; Tamosaitiene, J. 2009. Multi-attribute decision-making model by applying grey numbers, Informatica 20(2): 305-320.

Zavadskas, E. K.; Turskis, Z. 2008. A new logarithmic normalization method in games theory, Informatica 19(2): 303-314.

Zavadskas, E. K.; Vaidogas, E. R. 2008. Bayesian reasoning in managerial decisions on the choice of equipment for the prevention of industrial accidents, Inzinerine Ekonomika Engineering Economics 5: 32-40.

Zavadskas, E. K.; Turskis, Z.; Tamošaitiene, J. 2008a. Contractor selection of construction in a competitive environment, Journal of Business Economics and Management 9(3): 181-187. doi:10.3846/1611-1699.2008.9.181-187

Zavadskas, E. K.; Raslanas, S.; Kaklauskas, A. 2008b. The selection of effective retrofit scenarios for panel houses in urban neighbourhoods based on expected energy savings and increase in market value: The Vilnius case, Energy and Buildings 40(4): 573-587. doi:10.1016/j.enbuild.2007.04.015

Zavadskas, E. K.; Kaklauskas, A.; Turskis, Z.; Tamošaitienė, J. 2008c. Selection of the effective dwelling house walls by applying attributes values determined at intervals, Journal of Civil Engineering and Management 14(2): 85-93. doi:10.3846/1392-3730.2008.14.3

\section{STATYBOS PROJEKTU RIZIKOS VERTINIMAS}

\section{E. K. Zavadskas, Z. Turskis, J. Tamošaitienė}

\section{S a n tra u a}

Straipsnyje vertinama statybos projektų rizika. Vertinimas pagrịstas įvairiais daugiatikslio vertinimo metodais. Rizikos vertinimo rodikliai atrenkami, atsižvelgiant ị suinteresuotų šalių interesus, tikslus ir veiksnius, kurie turi itakos statybos proceso efektyvumui ir nekilnojamojo turto vertes didinimui. Projektai surikiuoti pagal naudinguma, nustatyti santykiniai jų optimalumo dydžiai. Uždavinio modeliui aprašyti ir jam išspręsti taikomi TOPSIS grey ir COPRAS-G metodai. Projektų savybės aprašomos efektyvumo rodiklių reikšmėmis, apibrèžiamomis intervaluose. Straipsnyje aprašomas taikomas modelis, atlikta uždavinio analizè ir pateikiamos trumpos išvados.

Reikšminiai žodžiai: sprendimų prièmimas, statyba, rizika, įvertinimas, rodikliai, TOPSIS grey, COPRAS-G, rangavimas.

Edmundas Kazimieras ZAVADSKAS. Doctor Habil, the principal vice-rector of Vilnius Gediminas Technical University and Head of the Dept of Construction Technology and Management at Vilnius Gediminas Technical University, Vilnius, Lithuania. He has a PhD in building structures (1973) and Dr Sc (1987) in building technology and management. He is a member of the Lithuanian and several foreign Academies of Sciences. He is doctore honoris causa at Poznan, SaintPetersburg, and Kiev. He is a member of international organisations and has been a member of steering and programme committees at many international conferences. E. K. Zavadskas is a member of editorial boards of several research journals. He is the author of over 50 books published in Lithuanian, Russian, German, and English. He has published more than 350 scientific papers. Research interests are: building technology and management, decision-making theory, grey relation, automation in design and decision support systems.

Zenonas TURSKIS. Doctor, a senior research fellow of Construction Technology and Management Laboratory of Vilnius Gediminas Technical University, Lithuania. He is the author of 1 book published in Lithuanian and 30 scientific papers. His research interests include building technology and management, decision-making in construction, computeraided automation in design and expert systems.

Jolanta TAMOŠAITIENĖ. Doctor, Dean assistant of Civil Engineering Faculty, Vilnius Gediminas Technical University, reader of the Dept of Construction Technology and Management, Vilnius Gediminas Technical University, Lithuania. BSc degree (building technology and management), Vilnius Gediminas Technical University (2000). MSc degree (Building management and economics), Vilnius Gediminas Technical University (2002). She published 9 scientific papers. Research interests: construction technology and organisation, construction project administration, decision-making and grey theory. 